\title{
ANALISIS PERUBAHAN GUNA LAHAN TERHADAP TINGKAT HAMBATAN SAMPING DI WILAYAH PEMBANGUNAN BANDARA DHOHO KEDIRI
}

\author{
Yoanita Eka Rahayu ${ }^{1)}$, M. Shofwan Donny Cahyono ${ }^{2)}$ \\ ${ }^{1,2)}$ Dosen Teknik Sipil Universitas Widya Kartika Surabaya \\ e-mail : yoanitaryandi@gmail.com. ${ }^{1)}$
}

\begin{abstract}
ABSTRAK
Perkembangan pembangunan infrastruktur di Jawa Timur terus dilakukan sebagai upaya untuk meningkatkan kesejahteraan masyarakat dan memulihkan ekonomi nasional, salah satunya adalah Pembangunan Bandara Dhoho Kediri. Proyek pembangunan bandara menempati wilayah di 3 kecamatan yaitu Tarokan, Grogol dan Banyakan. Permasalahan terjadi dikarenakan fungsi guna lahan yang berada di kawasan pembangunan bandara terutama di ruas Jl. Raya Kediri-Nganjuk mempunyai aktivitas yang cukup tinggi dan berpotensi meningkat seiring dengan pembukaan bandara pada tahun 2023. Dalam studi ini digunakan pendekatan analisis deskriptif kuantitatif dengan penginderaan jarak jauh menggunakan Citra Google Earth. Ruas jalan yang ditinjau adalah Jl. Raya Kediri-Nganjuk Simpang Banyakan sepanjang 5,79 $\mathrm{km}$ dan membagi menjadi 3 segmen sesuai dengan batas administratif per wilayah kecamatan. Hasil analisis persentase pertumbuhan guna lahan pada tahun 2013, 2017 dan 2022 (eksisting) menunjukkan pada Kec. Tarokan pertumbuhan rata-rata sebesar $7,529 \%$ dengan penambahan $2.173 \mathrm{~m}^{2}$, Kec. Grogol sebesar 5,002\% dengan penambahan $7.302 \mathrm{~m}^{2}$, Kec. Banyakan sebesar 7,175\% dengan penambahan $4.972 \mathrm{~m}^{2}$ untuk prediksi guna lahan tahun 2027 . Sedangkan untuk analisis hambatan samping tergambar sesuai dengan kondisi daerah dengan tingkat hambatan samping bervariasi dari sedang hingga sangat tinggi.
\end{abstract}

Kata kunci : hambatan samping, perubahan guna lahan, pembangunan bandara

\section{PENDAHULUAN}

Pembangunan infrastruktur di sebuah kota selain bertujuan untuk meningkatkan kesejahteraan masyarakat juga berpotensi sebagai alternatif pemulihan ekonomi nasional, lingkungan dan sosial. Pembangunan infrastruktur Bandara Dhoho Kediri merupakan upaya pemerintah dalam mengakomodir kebutuhan masyarakat akan transportasi udara yang terus meningkat (Kharisma,2019).

Pembangunan Bandara Dhoho Kediri menempati 4 desa dari 3 kecamatan yaitu Kec. Banyakan, Kec. Grogol dan Kec. Tarokan. Menurut PERDA Kab. Kediri No 4. Tahun 2019 menyebutkan bahwa Sistem Pusat Kegiatan sebagai pusat pemerintahan kecamatan dan pusat pelayanan sosial ekonomi skala kawasan terletak di beberapa kecamatan salah satunya adalah kecamatan Tarokan dan Banyakan. Sedangkan pada wilayah perkotaan kecamatan Grogol digunakan sebagai pusat pemerintahan kecamatan, pusat perdagangan regional dan pusat pendidikan.

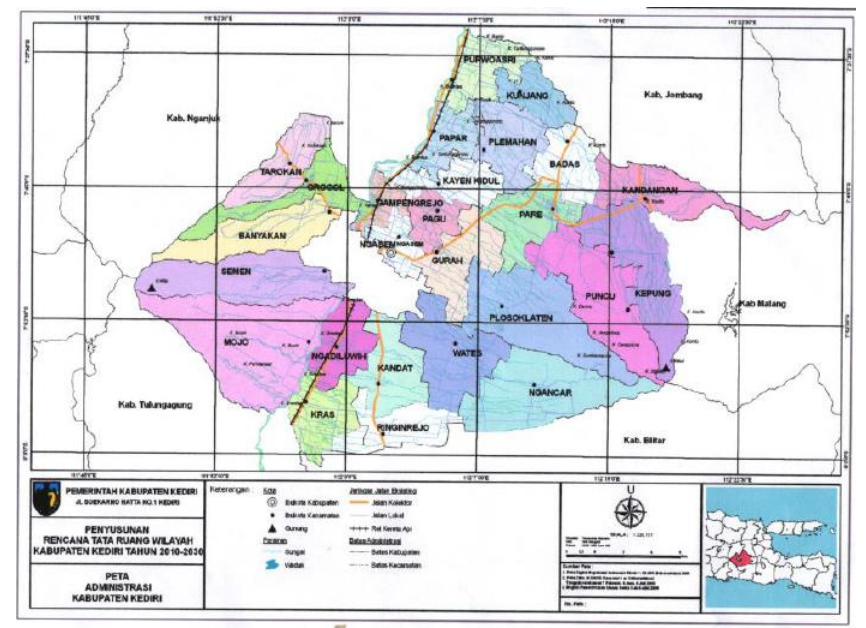

Gambar 1.1 Peta Administrasi Kota Kediri

(RTRW Kabupaten Kediri 2010-2030)

Aktivitas dari adanya kegiatan pembangunan Bandara Dhoho Kediri dan perkembangan guna lahan dari tahun ke tahun 
akan memberikan dampak terhadap kinerja $\mathrm{Jl}$. Raya Kediri-Nganjuk yang diakibatkan oleh peningkatan aktivitas yang tumbuh dan menyebabkan meningkatnya hambatan samping yang berada di sepanjang jalan tersebut. Sehingga perlu dilakukan analisis untuk mengetahui perubahan guna lahan terhadap tingkat hambatan samping di wilayah pembangunan Bandara Dhoho Kediri.

1.1 Gambaran Guna Lahan di Wilayah Pembangunan Bandara dari Citra Google Earth Pendekatan dan pengamatan deskriptif dilakukan dengan bantuan Citra Google Earth untuk melihat perubahan fungsi guna lahan di sepanjang ruas Jl. Raya Kediri-Nganjuk dari tahun 2013, 2017 dan 2022. Segmen pengamatan ditetapkan mulai dari pintu masuk Proyek Bandara Dhoho Kediri hingga Simpang Banyakan yang menjadi wacana sebagai Exit Tol Kediri-Kertosono. Berikut merupakan gambaran perubahan guna lahan dari tahun yang ditinjau.

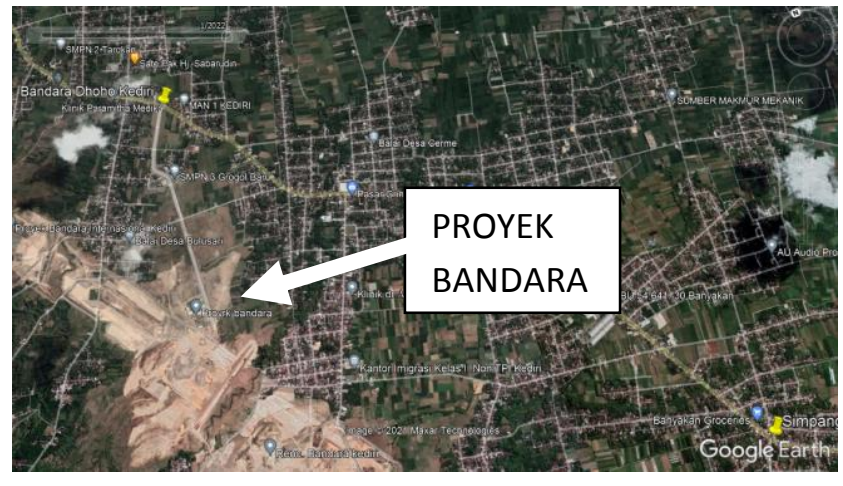

Gambar 1.2 Tata Guna Lahan di sepanjang Ruas Jl. Raya Kediri-Nganjuk Tahun 2022

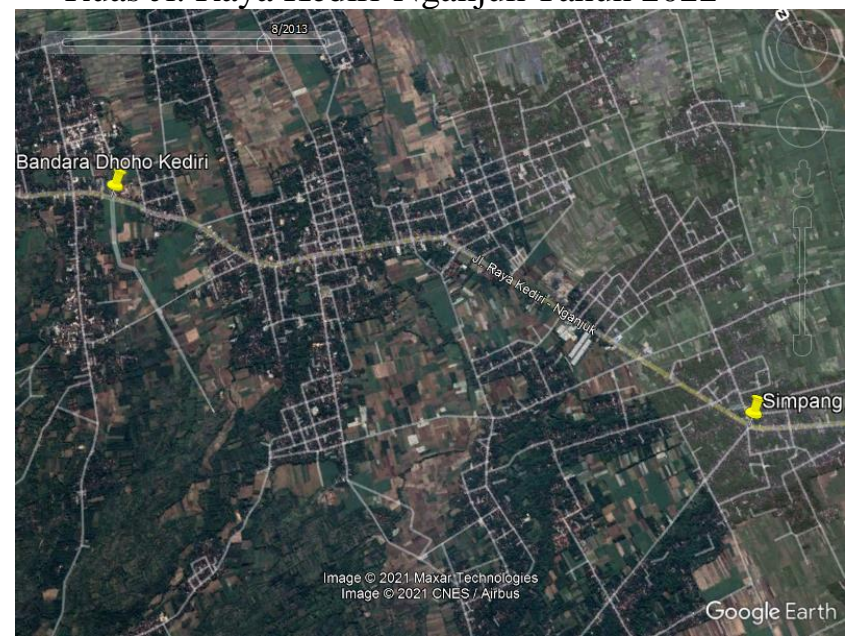

Gambar 1.3 Tata Guna Lahan di sepanjang Ruas Jl. Raya Kediri-Nganjuk Tahun 2013
Gambar 1.2 dan Gambar 1.3 memperlihatkan perubahan Guna Lahan yang diambil dari Citra Google Earth pada bulan Januari 2022 dan September 2013. Pada Tabel 1.1 terlihat adanya kenaikan penggunaan lahan bukan pertanian dari tahun 2018 hingga 2020. Menurut data dari Badan Pusat Statistik Kab. Kediri, kenaikan signifikan terjadi di kecamatan Tarokan yaitu dari 923 ha menjadi 1257 ha pada tahun 2020. Hal itu disebabkan karena adanya proyek pembangunan Bandara Dhoho Kediri dengan kebutuhan luas total lahan sekitar 321 ha. Evaluasi pola penggunaan lahan harus dikontrol secara teratur agar tidak menimbulkan beban pada jaringan jalan (Rahayu,2015).

Tabel 1.1 Penggunaan Lahan Bukan Pertanian (Ha) Tahun 2018-2020

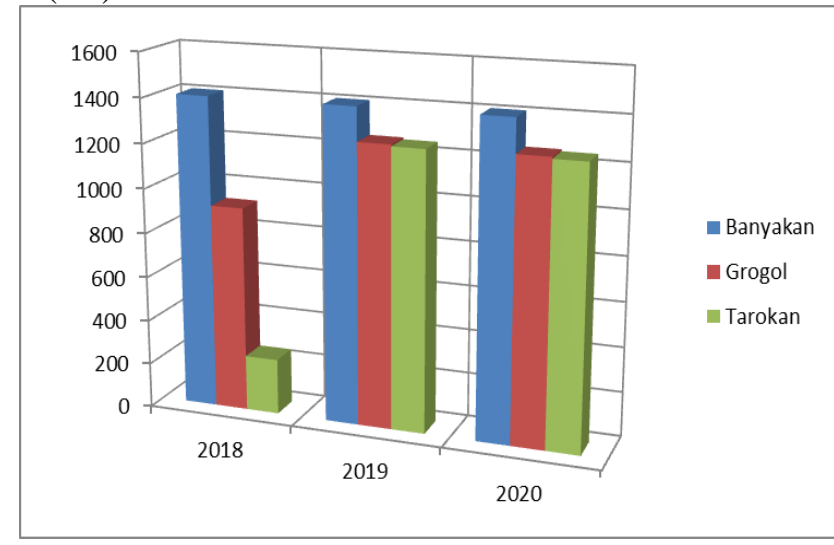

(Sumber : BPS Kabupaten Kediri)

\section{TINJAUAN PUSTAKA}

\subsection{Hubungan Tata Guna Lahan Dengan} Transportasi

Terbentuknya sebuah sistem transportasi guna lahan berasal dari keterkaitan hubungan antara transportasi dengan guna lahan. Guna lahan erat kaitannya dengan kegiatan/aktivitas manusia yang sebetulnya dibentuk dari tiga unsur yaitu manusia itu sendiri, aktivitas dan lokasi yang saling berinteraksi satu sama lain (Mayer \& Milller, 1984). Berbagai variasi tata guna lahan memiliki klasifikasi yang secara umum dibagi menjadi empat bagian yaitu pemukiman, jaringan transportasi, kegiatan industri/komersial, dan fasilitas pelayanan umum.

\subsection{Hambatan Samping \\ Hambatan samping merupakan aktivitas di samping jalan yang dapat}


berpengaruh pada pergerakan lalu lintas serta menurunkan kinerja jalan. Menurut ketentuan MKJI 1997, pengamatan frekuensi hambatan samping pada sebuah segmen jalan diamati berdasarkan pada jumlah pejalan kaki, jumlah kendaraan berhenti dan parkir, jumlah kendaraan keluar/masuk samping jalan atau sisi jalan dan kendaraan yang bergerak lambat. Tingkat hambatan samping dikelompokkan menjadi lima kelas, dari kelas sangat rendah sampai sangat tinggi sebagai gambaran aktivitas yang terjadi disepanjang jalan yang ditinjau.

\section{METODOLOGI}

Penelitian ini dilakukan dengan menggunakan analisis deskriptif kuantitatif yang menyatakan bahwa penelitian deskriptif sebagai upaya pemecahan masalah dengan cara menyajikan, mengidentifikasi, menggambarkan fenomena yang muncul dan diolah berdasarkan hasil temuan yang didapat (Setyawan, Karmilah, 2017). Menurut Sugiyono (2012:29), pengertian deskriptif merupakan sebuah metode untuk memberikan gambaran terhadap objek yang diteliti melalui data atau sampel yang telah dikumpulkan sebagaimana adanya. Sehingga, pendekatan deskriptif dapat digunakan sebagai upaya untuk menarasikan eksisting dari sebuah wilayah/kawasan hingga menjabarkan mengenai perkembangan yang akan terjadi di wilayah tersebut.

\section{ANALISIS DATA DAN PEMBAHASAN}

4.1 Analisis Pembagian Segmen Jalan (Studi Kasus: Jl. Raya Kediri-Nganjuk - Simpang Banyakan)

Pada Ruas Jl. Raya Kediri-Nganjuk dari pintu masuk Proyek Bandara Dhoho Kediri hingga Simpang Banyakan melewati 3 kecamatan yaitu Tarokan, Grogol dan Banyakan. Panjang Ruas yang dijadikan studi dalam penelitian adalah sepanjang $5,79 \mathrm{~km}$. Sehingga untuk pengamatan hambatan samping yang berpengaruh pada ruas jalan tersebut akan dibagi menjadi 3 segmen sesuai batas pembagi dalam wilayah kecamatan. Segmen 1 adalah kecamatan Tarokan sepanjang 1,22 km. Segmen 2 adalah Kecamatan Grogol sepanjang 3,08 km dan pada Segmen 3 adalah kecamatan Banyakan sepanjang 1,49 km. Penjelasan mengenai pembagian segmen bisa dilihat pada gambar 3.1 .

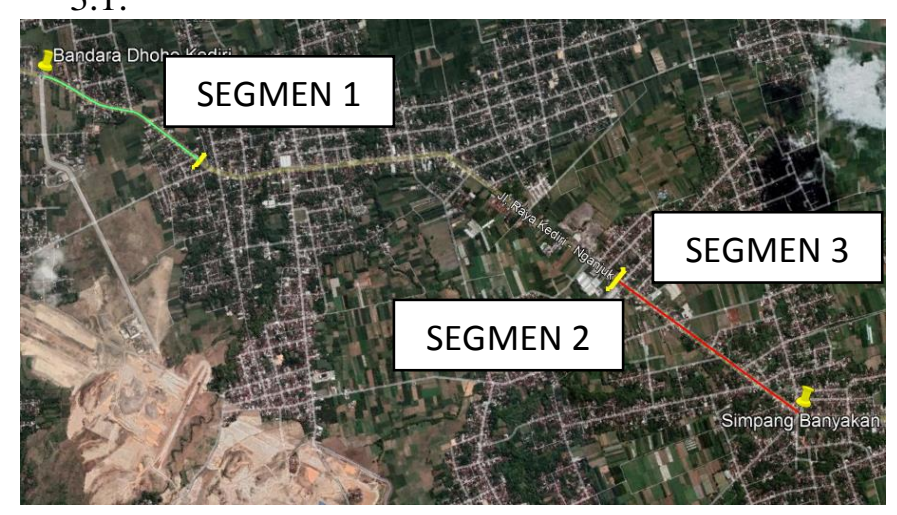

Gambar 4.1 Pembagian Segmen Pada Wilayah Studi Ruas Jl. Raya Kediri-Nganjuk

\subsection{Analisis Pertumbuhan Penggunaan Lahan di Wilayah Studi \\ Dari hasil pengamatan melalui Citra} Google Earth, pada wilayah studi tergambar penggunaan lahan yang menimbulkan aktivitas cukup tinggi. Untuk mendapatkan nilai persentase pertumbuhan penggunaan lahan pada 3 segmen yang ditinjau, maka perlu dibuat tabel perbandingan penggunaan lahan eksisting dan beberapa tahun sebelumnya. Setelah dilakukan analisis, diharapkan akan dapat menggambarkan persentase pertumbuhan pada beberapa tahun mendatang. Berikut ini merupakan tabel hasil pengamatan penggunaan lahan di wilayah studi. Sampling guna lahan yang ditinjau dikaitkan dengan fungsi bangunan yang memberikan dampak aktivitas yang relatif sedang-tinggi.

Tabel 4.1 Pertumbuhan Penggunaan Lahan tahun 2013, 2017 dan 2022

\begin{tabular}{|c|c|c|c|}
\hline \multirow{2}{*}{ Kecamatan } & \multicolumn{3}{|c|}{ Perubahan Guna Lahan m2 } \\
\cline { 2 - 4 } & $\mathbf{2 0 1 3}$ & $\mathbf{2 0 1 7}$ & $\mathbf{2 0 2 2}$ \\
\hline Kec.Tarokan & 24682 & 26648 & 28865 \\
\hline Kec.Grogol & 131173 & 137919 & 145411 \\
\hline Kec. Banyakan & 59691 & 63359 & 69291 \\
\hline
\end{tabular}

Sumber : Hasil analisis, 2022. 


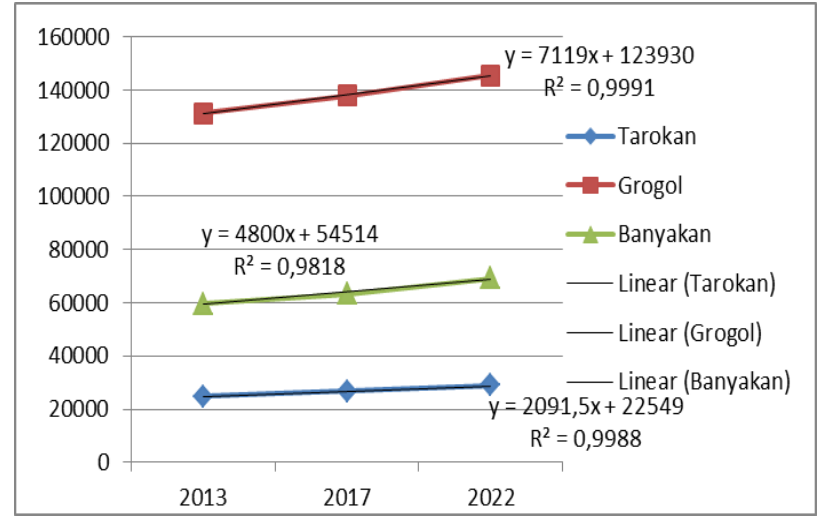

Gambar 4.2 Grafik Pertumbuhan Guna Lahan di 3 segmen tahun 2013,2017 dan 2022

(Sumber : Hasil analisis, 2022)

Menurut hasil perhitungan didapatkan persentase pertumbuhan guna lahan pada 3 segmen, antara lain:

- Kecamatan Tarokan

$\rightarrow$ Tahun 2013-2017 =7,378\%

$\rightarrow$ Tahun $2017-2022=7,680 \%$

$\rightarrow$ Pertumbuhan rata-rata $=7,529 \%$

- Kecamatan Grogol

$\rightarrow$ Tahun 2013-2017 $=4,891 \%$

$\rightarrow$ Tahun $2017-2022=5,152 \%$

$\rightarrow$ Pertumbuhan rata-rata $=5,022 \%$

- Kecamatan Banyakan

$\rightarrow$ Tahun 2013-2017 =5,789\%

$\rightarrow$ Tahun $2017-2022=8,561 \%$

$\rightarrow$ Pertumbuhan rata-rata $=7,175 \%$

4.3. Analisis Fungsi Guna Lahan dan Hambatan Samping di Wilayah Studi

Hambatan samping adalah dampak terhadap kinerja lalu lintas yang berasal dari aktivitas samping segmen dan sangat berpengaruh pada tingkat pelayanan di suatu ruas jalan (Kristiawan,2019). Hambatan samping juga berpengaruh terhadap kecepatan kendaraan yang melalui jalan tersebut yang menyebabkan berkurangnya kapasitas dan mempengaruhi tingkat kinerja jalan.

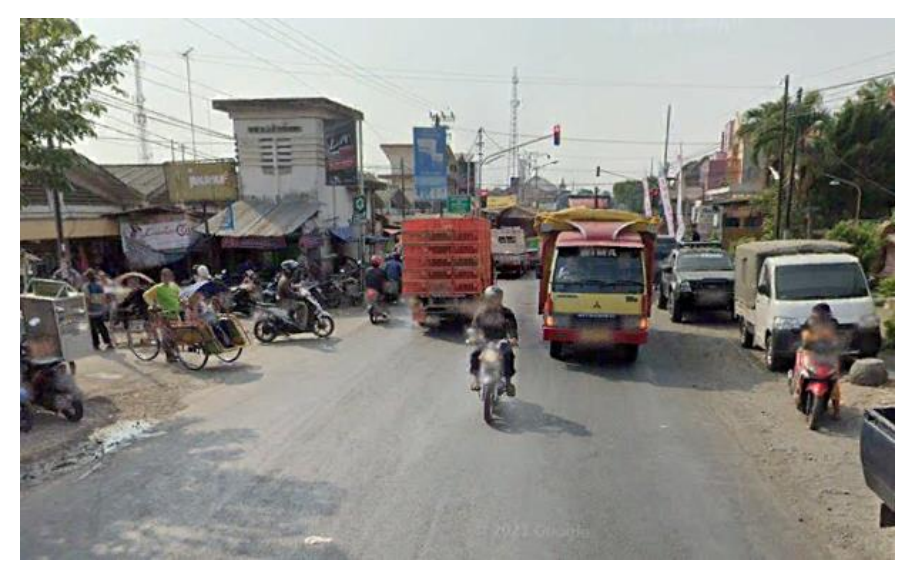

Gambar 4.3 Kondisi Penggunaan Bahu Jalan untuk kendaraan parkir di sekitar pasar Gringging (Segmen 2)

Tetapi untuk batasan penelitian ini hanya dilakukan pendekatan berdasarkan kondisi daerah dikarenakan pengamatan hanya dilakukan melalui penginderaan citra jarak jauh.

Tabel 4.2 Nilai Kelas Tingkat Hambatan Samping (MKJI, 1997)

\begin{tabular}{|c|c|c|l|}
\hline $\begin{array}{c}\text { Kelas } \\
\text { Hambatan } \\
\text { Samping } \\
\text { (SCF) }\end{array}$ & Kode & $\begin{array}{c}\text { Jumlah } \\
\text { kejadian } \\
\text { per } \\
200 \mathrm{~m} / \text { jam }\end{array}$ & \multicolumn{1}{|c|}{ Kondisi Daerah } \\
\hline $\begin{array}{c}\text { Sangat } \\
\text { Rendah }\end{array}$ & VL & $<100$ & $\begin{array}{l}\text { Daerah pemukiman; } \\
\text { hampir tidak ada } \\
\text { kegiatan. }\end{array}$ \\
\hline Rendah & L & $100-299$ & $\begin{array}{l}\text { Daerah pemukiman; } \\
\text { berupa angkutan umum } \\
\text { dsb. }\end{array}$ \\
\hline Sedang & M & $300-499$ & $\begin{array}{l}\text { Daerah Industri; } \\
\text { beberapa toko di sisi } \\
\text { jalan. }\end{array}$ \\
\hline Tinggi & H & $500-899$ & $\begin{array}{l}\text { Daerah komersial; } \\
\text { aktivitas sisi jalan yang } \\
\text { sangat tinggi. }\end{array}$ \\
\hline $\begin{array}{c}\text { Sangat } \\
\text { Tinggi }\end{array}$ & VH & $>900$ & $\begin{array}{l}\text { Daerah komersial; } \\
\text { aktivitas pasar disamping } \\
\text { jalan. }\end{array}$ \\
\hline
\end{tabular}




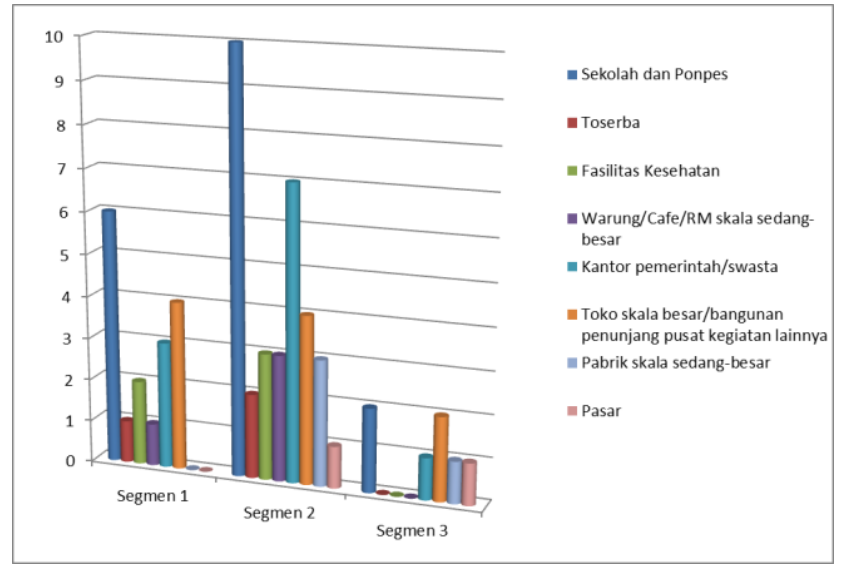

Gambar 4.4 Grafik Penggunaan Lahan di Wilayah Studi yang menimbulkan hambatan samping di ruas Jl. Raya Kediri-Nganjuk

\section{KESIMPULAN DAN SARAN}

Berdasarkan hasil analisis perubahan guna lahan yang dilakukan di wilayah studi (Jl. Raya Kediri-Nganjuk - Simpang Banyakan) didapatkan hasil, antara lain:

\section{- Segmen 1 (Kecamatan Tarokan)}

Persentase pertumbuhan guna lahan rata-rata yang ditinjau dari tahun 2013,2017 dan 2022 adalah sebesar 7,529\%. Sehingga, untuk prediksi 5 tahun ke depan yaitu pada tahun 2027 diperkirakan akan terjadi peningkatan penggunaan lahan sebesar $2173 \mathrm{~m}^{2}$. Tingkat hambatan samping yang terjadi di Segmen 1 eksisting menunjukkan kelas hambatan samping Sedang hingga Tinggi pada jam-jam tertentu. Hal itu diakibatkan karena adanya 17 bangunan yang memberikan pengaruh pada tingkat aktivitas yang terjadi Ruas Jl. Raya KediriNganjuk ditambah dengan penambahan bangunan non permanen yang tumbuh di bahu jalan.

\section{- Segmen 2 (Kecamatan Grogol)}

Persentase pertumbuhan guna lahan rata-rata yang ditinjau dari tahun 2013,2017 dan 2022 adalah sebesar 5,002\%. Sehingga, untuk prediksi 5 tahun ke depan yaitu pada tahun 2027 diperkirakan akan terjadi peningkatan penggunaan lahan sebesar $7302 \mathrm{~m}^{2}$. Tingkat hambatan samping yang terjadi di Segmen 2 eksisting menunjukkan kelas hambatan samping Tinggi hingga Sangat Tinggi pada jam dan ruas tertentu. Hal itu diakibatkan karena adanya 33 bangunan yang memberikan pengaruh pada tingkat aktivitas yang terjadi Ruas Jl. Raya
Kediri-Nganjuk. Keberadaan pasar Gringging pada segmen 2 ditambah dengan adanya 10 fasilitas pendidikan dapat memberikan pengaruh terhadap Kinerja Lalu Lintas di sepanjang ruas jalan.

- Segmen 3 (Kecamatan Banyakan)

Persentase pertumbuhan guna lahan rata-rata yang ditinjau dari tahun 2013,2017 dan 2022 adalah sebesar 7,175\%. Sehingga, untuk prediksi 5 tahun ke depan yaitu pada tahun 2027 diperkirakan akan terjadi peningkatan penggunaan lahan sebesar $4972 \mathrm{~m}^{2}$. Tingkat hambatan samping yang terjadi di Segmen 3 eksisting menunjukkan kelas hambatan samping Rendah hingga Sedang pada jam-jam tertentu. Keberadaan Pasar Banyakan tidak terlalu membebani ruas jalan karena adanya pembagian pintu dari sisi ruas jalan yang lain. Ruas jalan di segmen 3 masih belum didominasi oleh pertokoan di sepanjang jalan.

Sebagai rekomendasi yang diajukan berdasarkan hasil kesimpulan dari analisa yang dilakukan, perlu adanya penataan lalu lintas dilihat dari beberapa bangunan yang menunjukkan tingkat aktivitas yang tinggi. Terkait dengan rencana pembukaan Bandara Dhoho Kediri, apabila ruas Jl. Raya Kediri-Nganjuk digunakan sebagai jalur menuju bandara harusnya Pemerintah Kabupaten Kediri harus mulai menerapkan upaya penertiban bahu jalan dan memperketat pemberian ijin bangunan yang bisa berdampak pada kinerja jalan akses menuju bandara.

\section{DAFTAR PUSTAKA}

[1] Kharisma, Fajar, 2019, Dampak Pembangunan Bandara Kediri Terhadap Perubahan Sosial Ekonomi Masyarakat (Studi pada Masyarakat Desa Grogol, Kec. Grogol, Kab. Kediri), UMM, Malang.

[2] Kristiawan, Deril. Najid., 2019, Analisis Pengaruh Hambatan Samping Akibat Aktivitas Guna Tata Guna Lahan di Jalan MH. Thamrin Tangerang dan Jalan Raya Serpong, Jurnal Mitra Teknik SipiL, vol. 2, no. 4.

[3] Manual Kapasitas Jalan Indonesia (MKJI, 1997) 
[4] Rahayu, Yoanita Eka, 2016, Analisis Kualitas Perjalanan Akses Bandara Internasional Juanda Terkait Perkembangan Tata Guna Lahan Kota Surabaya. Master thesis, Institut Teknologi Sepuluh Nopember.

[5] Setyawan, Taufik. Karmilah, Mila., 2017, Dampak Guna Lahan Terhadap Tingkat Kemampuan Kinerja Jalan, Jurnal Planologi, vol. 14, no.1.

[6] Sungkono, Nandang., 2020, Analisis Dampak Pembangunan Bandara Yogyakarta International Airport (YIA) Terhadap Kinerja Ruas Jalan Karangnongko (BTS Prov. Jateng) Toyan, Universitas Islam Indonesia. 